\title{
Legality, Social Research, and the Challenge of Institutional Review Boards
}

Malcolm M. Feeley

\section{Legality and the Law \& Society Tradition}

\section{I}

n a wonderful new book, Law as a Means to an End: Threat to the Rule of Law, Brian Tamanaha (2006) picks up on a debate that graced the pages of the Law $\mathcal{E}$ Society Review 40 years ago. In Volume 1, No. 1, the kickoff issue, law professor Carl Auerbach (1966) invited social scientists to help lawyers chart the law's effectiveness and design more effective laws. Sociologist Jerome Skolnick (1966) demurred; drawing on the work of his colleague Philip Selznick (1969), he rejected the instrumentalist agenda Auerbach offered, arguing that the task of the sociology of law was to identify the social conditions in which legality emerges and flourishes. Tamanaha writes as if Auerbach won the debate. His subtitle boldly announces his thesis. Tamanaha's book, though not written with Auerbach in mind, is a reaction to the type of instrumentalism that Auerbach advocated. Tamanaha accuses legislators, judges, sociolegal scholars, and particularly legal scholars of ignoring - indeed, abandoning - the concern with justice, and of exchanging it for a narrow utilitarian conception of law. In so doing, he laments, law delves too deeply into cost-benefit policy analysis, endangering its autonomy, and its concerns with justice.

The trend Tamanaha identifies is clearly observable. Witness the triumph of legal realism. Witness the rise of law and economics - and the subordination of law to the principle of utility, a shift that has transformed law into a branch of applied economics and

Presidential Address delivered at the Annual Meeting of the Law \& Society Association, Baltimore, Maryland, July 8, 2006. In preparing this piece, I have benefited enormously from conversations with a number of colleagues, including Howie Erlanger, Rosann Greenspan, Christine Harrington, Bob Kagan, Jack Katz, Felice Levine, John Mueller, Laura Stark, Brian Tamanaha, and Dvorah Yannow. Needless to say, the views expressed are my own. Please address comments to Malcolm M. Feeley, Jurisprudence and Social Policy Program, Boalt Hall School of Law, 2240 Piedmont Avenue, University of California, Berkeley, CA 94720; e-mail: mmf@law.berkeley.edu. 
produced what David Driesen (2002) has called a new natural law theory with the Coase Theorem at its core. It may be that the "mysterious science" can only be deciphered through the "dismal science."

It is not clear, however, that Tamanaha is correct-that instrumentalism now thoroughly pervades the academy. At least with respect to the tradition of the Law \& Society Association, he may be overstating the case. Indeed, the position outlined by Skolnick seems to inform much of the scholarship of contributors to this Review. Certainly, members of this Association have rejected the notion that social scientists should become, in David Trubek's phrase, the law's "handmaidens" (1988). To the extent that instrumentalism is present in the scholarship of Association members, it is usually in due context, proportion, and moderation. Although instrumentalism certainly looms large in our field, hyperinstrumentalism certainly does not dominate our house of many mansions (Erlanger 2005).

Of course, today many members of the Association hold a more jaded view of law and the legal process than they or their counterparts did in 1966, and this may be part of the resistance to hyper-instrumentalism, which is what I think Tamanaha really objects to. Shifting politics, postmodernism, critical theories of various stripes, and the cultural turn have all taken their toll on instrumentalist optimism about "knowing," both knowing the social conditions that give rise to law, legality, and the legal system, and knowing enough to construct (or even advocate) effective programs to remedy the pathologies of the existing social order. But single-minded instrumentalism has by no means come to dominate our discourse. Indeed, something of the opposite may be true (Scheingold \& Sarat 2004, 2005).

Many intellectual currents during the past 40 years since the founding of this Association have challenged optimistic instrumentalism and required us to excavate our epistemology in order to anchor our research on more solid foundations, or at least to secure them more firmly on the sands of doubt. Disappointment and skepticism do not indicate rejection of foundational concerns and the quest for justice, and they certainly do not reflect an embrace of instrumentalism. Indeed, disillusionment-even cynicism-may testify to the endurance of idealism. Many sociolegal scholars who critique the contemporary legal process have not abandoned law for instrumentalism, but report that legal institutions have too often abandoned law. What they find is not bad law, but corrupt law or no law at all. Consider: as Austin Sarat (2005) and his colleagues dissect the death penalty, they find that the law itself has died from lack of embrace. Marianne Constable (2005), in a harsh condemnation of legal instrumentalism, tells us that, in modern law, justice 
is revealed only in the law's silences. Lauren Edelman (Edelman et al. 1993) now heads a vast school of new institutionalist sociolegal scholars that shows how the law's conscience is routinely abandoned for institutional convenience.

Browse through any of the 150-odd issues of the Law E' Society Review from its 40 years of publication, and you'll find a wealth of jurisprudentially informed sociolegal studies. Implicit, if not explicit, in many articles are conceptions of law that resonate with the works of Lon Fuller, Philip Selznick, and other early advocates of the Association-as well as other scholars such as Dworkin, Raz, Rorty, Geertz, Waldron, and Habermas, whose jurisprudentialrelated writings have profoundly influenced subsequent sociolegal scholarship.

Given what I have just said, my obvious next step should be to set out a detailed understanding of a jurisprudentially robust concept of law, one that draws on the aforementioned traditions implicit in so much law and society scholarship. That is, I might counter Tamanaha by showing the continuing influence of Hart, Fuller, Selznick, Dworkin, Rorty, Habermas, Weber, and others in this Review's published work. I should then proceed to outline an agenda for the course of sociolegal studies in light of this vision. I am tempted to do this, and indeed have reflected a bit on this task elsewhere (Feeley 2005). But I shall resist. Instead, I want to offer three very instrumental (!) reasons why this Association needs to affirm Tamanaha's call for a more jurisprudentially anchored understanding of law.

First, such an understanding is necessary if Association members (particularly American members, who are most likely to be influenced by instrumentalism) are to engage fully in embracing globalism. Second, it is necessary if Association members are to engage in the equivalent of what ASA [American Sociological Association] President Michael Burawoy (2005) has called "public sociology." And third, it is necessary if we are to protect the conditions under which we pursue our own research. I will explore each of these reasons in turn-the first two only briefly, and the third at some length since it most directly threatens our scholarly enterprise.

\section{Influences of Legal Globalization and Public Sociology}

It behooves us as researchers to embrace a jurisprudentially rich concept of law if we are to engage in the process of legal globalization. If we embrace the American-style hyper-instrumentalism that, according to Tamanaha, saturates American thinking about law, American sociolegal scholars will simply miss much of 
what goes on in law, in legal discourse, and in legal scholarship around the world. The quest for-and the language of-justice looms larger in some legal cultures than in others, as does the idea that law is a system of discourse and not a means to an end. The inability to appreciate these various modes of organizing behavior and of scholarly thought can all too easily make instrumentalists tone-deaf to many legal and scholarly developments around the world. Indeed, the problem may even stem, in part, from the deficits of the English language. Owing to the Norman conquest, English has twice as many words as other European languages, but with respect to law, English may have only half the vocabulary. It has one term - law - while French has le droit and le loi, and German has Recht and Gesetz. Americans at times have tried to distinguish between law and Law, but this stylistic affectation has never taken root.

So if Americans arguably owe it to colleagues around the world to embrace a broad and jurisprudentially robust conception of law, we unquestionably owe it to ourselves if we are to engage fully in their concerns. Moreover, we certainly owe it to the quest for truth to explore the aspirational qualities inherent in any robust concept of law. This statement, I suspect, is obvious to all but the most dogged positivists among us. Indeed, there are many reasons to be sensitive to the inner morality of the legal order: it pushes us to explicate our own values, and it alerts us to an important distinction in many legal systems between "law" and "administration"the type of instrumentalism Tamanaha examines.

More simply, though, this sensitivity is necessary if we are to grasp important features of the legal order in less instrumentally minded countries. My non-American friends and colleagues, I hope-especially Andreas Abegg, Roger Cotterrell, David Nelken, Takao Tanase, and William Twining-have weaned me of my American penchant for legal hyper-instrumentalism so that, for example, I can better appreciate Italy's seemingly endless judicial process, or Gunthner Teubner's $(1983,1984)$ compelling theory of the autopoeisis of law, which understands law as a system of communication. I will return to this theme shortly.

\section{Toward Public Sociolegal Studies}

I commend to you Michael Burawoy's 2004 Presidential Address to the ASA (2005), which calls for a "public sociology." Burawoy notes the growing interest among sociologists in addressing timely issues, as well as the "growing gap between the sociological ethos and the world we study" (2005:4). His challenge-the challenge for sociology generally, as he sees it -is to reconcile the 
concerns of critical and policy-oriented sociologists, who confront social problems, and "professional sociologists," who eschew policy-related discussion in their quest for "pure" science.

Burawoy's address explores the symbiotic relationship between the "socially relevant" and the "pure" sociologist. Contrary to conventional wisdom in the discipline, Burawoy argues, these two approaches are not in conflict, and indeed are mutually dependent. He writes that both share the same focus, namely a quest to explicate the salient organizational features of society. Burawoy notes that while "high" sociology "presents itself as universal" (2005:9), it is in fact "particular" in content as well as in form. For instance, he notes, "Between the 1960 s and the turn of the century, political sociology turned from [examining] the virtues of electoral democracy to studying the state and its relations to class, social movements as political processes, and the deepening of democratic participation" (2005:6). Professional sociologists might account for this in terms of scientific and theoretical advances, but Burawoy suggests that there is probably a more prosaic reason: New Dealand Great Society-oriented sociologists, repelled by a newly ascendant Republican majority, shifted their attention away from electoral politics to focus on other forms of (potentially progressive) political engagement in which to place their faith.

Burawoy is sympathetic to public sociology and critical of the parochialism of American pure or professional sociologists, but he does not call for the abandonment of professional sociology. Rather, he sees a symbiosis and seeks reconciliation. He writes, "Professional sociology is not the enemy of policy and public sociology but the sine qua non of their existence, providing both the legitimacy and the expertise for policy and public sociology" (2005:10). That is, both critical and public sociology will lack conviction and will merit dismissal as ad hoc instrumentalism if not grounded in the expertise of "professional" sociology.

Considering Burawoy's thesis in light of law and society research, I suggest that one component of "professional" law and society scholarship is a robust and jurisprudentially rich concept of law, legality, and legal system. Without them, our critical and public sociolegal research will be rightly perceived as the ad hoc instrumentalism against which Tamanaha warns. But the tension between "pure" and "public" social science that Burawoy explores with regard to sociology does not loom so large in law and society scholarship. Sociolegal scholars consistently anchor their work in a concern with broad principles of justice implicit in the concept of law. Few studies in our field propose a "pure science" of the sociology of law (compare Black 1980). Even those whose work is inspired by the grand tradition of Marx, Durkheim, and Weber, or of the luminaries in organization or systems theory, rarely purport 
to offer a universal theory. Furthermore, the contemporary social theory that informs much recent law and society scholarship explicitly eschews grand generalization. Although law appears to be universal across time and place, laws-plural-are anchored in history, time, and place, and so must be understood in context. Thus the quest is often for "local knowledge," the distinctive, even as underlying issues are generic and universal. As such, law and society scholarship is usually a mixture of "pure" and "public" inquiry, the general as articulated in and affected by the specific. Social problems and contextual justice are central to our concerns. These are the issues - the general principles underlying legality and the particulars of time and place-that I want to join together in the rest of my discussion.

\section{Protecting Research Subjects versus Protecting Research Scholars: The Challenge of Institutional Review Boards}

The discussion above, I confess, has been a wind-up for what is really on my mind: the largely self-inflicted wounds of institutional review boards (IRBs), which have become part of our research landscape over the past 30 years. In the space permitted me below, I want to explore this development in light of the points made above. This is a crucial issue for members of this Association, particularly American members who conduct social science research on human subjects and must receive prior approval of this research by ethics review committees. This review process places enormous burdens on empirical researchers and thus dramatically affects the nature and form of social science inquiry.

Until recently, discussions of problems with IRBs have not been aired widely. They have occasioned much grumbling by faculty and graduate students, as well as a number of panels at professional association meetings. At times they have been dealt with at the top: the National Academy of Sciences has convened heads of professional associations and federal funding agencies to rethink IRB administration, and at times the professional associations have addressed the issue. But among research scholars-researchers in the field - the issues still remain ill-defined and largely only whispered about. Atomized researchers respond individually as if the problems are theirs alone. In the face of IRB resistance, some have abandoned their projects, or found ways to circumvent or accommodate IRB requirements. But these makeshift solutions have been purchased at a high price, particularly by junior faculty and graduate students who lack the authority to stand up to unreason. Increasingly, however, this issue has been opened up to more widespread and serious discussion and those engaged in fieldwork. 
Over the years Jack Katz (2006) and other field researchers have been increasingly vocal in raising questions and challenging IRB hegemony. More recently, legal scholars have begun to weigh in, perhaps in response to the realization that more of their research than they had imagined in fact requires IRB approval (Hamburger 2004; Northwestern University Law Review 2007). One hopes that as the growing number of empirically oriented law faculty and campus-based journalists find that they too are subject to IRB strictures, discussion will expand still more and become even more vigorous, and a countervailing resistance, grounded in rights language, will emerge. The symposium on IRBs published in the Northwestern University Law Review (2007) is an encouraging sign.

\section{Background}

As a postdoctoral student at Yale 35 years ago, I once bumped into the distinguished sociologist Al Reiss, who promptly invited me to lunch. He carried under his arm a clutch of papers that he had just received at a conference in Washington and was anxious to talk. The conference had been sponsored by the major national funding agencies-NIH, NIMH, and NSF-and called in response to a new, rising concern with ethical standards in social science research. The task addressed by conference participants, including $\mathrm{Al}$, was that of devising ethical standards for research involving human subjects, and then establishing a process for enforcing them. Their emerging plan was to develop a self-enforcement mechanism that would ward off more far-reaching oversight by Congress or federal agencies - the classic reaction of any wouldbe regulated industry. In a nutshell, the proposal $\mathrm{Al}$ outlined to me that afternoon was to condition receipt of federal funds upon guarantees that the research proposals would be vetted by local ethics committees at their home institutions.

I was in the midst of researching the criminal process in New Haven, hanging around court all day and talking to everyonereporters, bail bondsmen, bailiffs, defendants, victims, witnesses, judges, defense attorneys, prosecutors, gallery audiences, police, everyone-so of course I was quite interested in what $\mathrm{Al}$ had to say. I listened intently and asked numerous questions.

After lunch, as we left Mory's and walked down High Street, Al showed me a set of proposed guidelines that had received tentative approval at the Washington meeting. I cannot recall their language, but I distinctly recall my reaction: "Al," I said, "this rule would require me to first get permission from the occupants of those cars at the corner of High Street and Whaley Avenue if I wanted to conduct a study that correlates the make of the cars with the number of occupants. Right?" 
"Correct," he replied, "but don't worry." He assured me that such sweeping principles would soon give way to narrow and nuanced provisions. After all, he continued, researchers themselves would refine and apply the rules; a sensible common law would emerge.

Al, who passed away last year, was almost always right on almost everything. But on this, his optimistic prediction was flat-out wrong. Rather than a common law-like process that developed narrow rules in response to limited, well-defined problems, we have seen the adoption of a federal law requiring the ethical review of all federally funded research that affects human subjects, the emergence of sweeping regulations and guidelines, and the emergence of a vast bureaucracy -in Washington, in the learned societies, in the universities - that oversees this law and derivative regulations. This process has spawned an aggressive enforcement process at universities across the country, and these regulatory powers are enhanced by risk-averse university administrators and atomized faculty researchers who passively accept the consequences. It casts its net over a vast range of work - far more vast than anything originally intended, and indeed much more than is necessary under current federal law, which requires only that federally funded research be vetted by such committees. Most universities have extended this requirement to apply to all research, whether funded by federal sources, funded by other sources, or wholly unfunded. This vast "licensing authority," as Philip Hamburger (2004) calls it, threatens the research of countless scholars.

\section{IRBs Institutionalized}

Before I turn to criticize this development, let me be clear: there is good reason to be concerned about ethics in social science research. Universities have a duty to sensitize researchers to ethical boundaries. Those who harm their research subjects should be sanctioned, and those who are harmed need redress. But we must distinguish between some problematic forms of biomedical research, on the one hand, and the bulk of social science fieldwork, on the other. And we need to guard against risk-averse instrumentalism that embraces an expansive regulatory regime when none is needed and when more modest and effective responses are available.

Campus committees established under federal law are now generically called institutional review boards, or IRBs (though, on my campus, the Committee for the Protection of Human Subjects is known to graduate students as the Committee for the Prevention of Research on Human Subjects). These committees are charged with reviewing research proposals to determine if they pose risks to 
human subjects. If these committees perceive such risks, they may request that research protocols be revised to better protect subjects. If researchers do not receive IRB approval, the campus will not permit the research to go forward, and federal funds cannot be used to support it. Researchers who evade these requirements risk dismissal; journals that publish such research risk severe sanctions - even if it can be demonstrated that no harm to subjects occurred. The stakes for noncompliance are high.

Further, though federal regulations do not require it, most campuses-indeed, virtually all American universities-have applied IRB procedures to all non-federally funded and unfunded research as well. The rationale offered for this is a combination of principle and practicality. If ethical standards are important, they should be applied to research without regard to particular sources of funding. And if there is an effective enforcement mechanism already in place to vet larger-scale projects that are funded by prestigious sources, it makes sense to apply that mechanism to other research as well. The result has been the emergence of an elaborate bureaucracy to vet social science research. Contrary to Al Reiss's prediction, it has neither narrowly tailored its concerns nor focused on a handful of real problems. The reverse has occurred: the process has expanded exponentially over the past 30 years, spawning an immense bureaucratic apparatus that is poised to consider the remotest risk. In an increasingly risk-averse environment, IRBs employing an instrumentalist cost-benefit analysis regularly withhold approval or require significant research modifications in order to preempt speculative harms.

In short, in the name of minimizing risks, IRBs subject researchers to petty tyranny. Graduate students and junior scholars are particularly likely to be caught in their web-and for them IRB tyranny is often more than petty. Senior scholars are generally more adept at avoidance, evasion, and adaptation, but they too are hardly exempt from this tyranny. A number of prominent social scientists, including some members of this Association, know all too well the harms of running afoul of campus IRBs.

IRBs are not advisory boards. They tell you what you can and cannot ask, what you can and cannot do. They can suppress data. They can prohibit publication. They are powerful. Here, it is important to consider the biomedical model implicit in this procedural structure. No one, I take it, would object to the requirement of rigorous protocols and informed consent in the testing of new drugs, or in experiments with new medical procedures. However, it seems inapt that, after 30 years, social science research would still be assessed according to a biomedical model, its disciplinary distinctiveness largely ignored. Indeed, the expansive regulatory approach toward the social sciences is at odds with the critical nature 
- the praxis-of the social science research that Michael Burawoy celebrated in his 2004 address. Under existing IRB protocols, much of the work he cites as models of public and critical sociology could not be conducted if IRBs exhaustively fulfilled their missions, or if the authors of those works had positions in today's universities. IRBs, as they have developed, pose an impediment to Burawoy's call for a socially relevant and critical sociology. They have taken on the form and function of censorship boards, and as such the universities that embrace them uncritically indulge community standards rather than provide researchers with a shield against them, as has been one of their traditional functions.

Let me catalogue some of the troublesome issues about and actions of IRBs. ${ }^{1}$ What follows is hardly a comprehensive survey or an unbiased sample. But it does represent issues that have been raised repeatedly by my colleagues and graduate students, frequently enough to suggest that the issues are not idiosyncratic oddities.

1. The IRB review process, in effect, imposes a licensing requirement to conduct research. Researchers must be licensed by the federal government through a power delegated to universities and then to research committees, and this power expands rather than contracts as it is transferred down the chain of authority. If you are not licensed, you cannot conduct research. Some have argued that this licensing amounts to prior restraint and hence contravenes the American constitutional tradition of free expression (Hamburger 2004).

2. Even if a study involves subjects who are public officials, namely those who are experienced in fielding office-related questions by hard-nosed investigative reporters, researchers still must submit proposals-including a list of questions to be asked, a list of expected findings, a statement of the work's social significance-to their campus IRBs. The IRB, not the researcher, determines whether a project qualifies for a

1 There is a dearth of systematic research on the operations and consequences of IRBs. For years I have occasionally urged my graduate students to undertake dissertation work that would compare IRB operations across the University of California campuses in light of my colleague Philip Selznick's ideas of legality, but so far none have taken me up on it. As part of my preparation for this article, however, I was pleased to learn that there has been at least one similar effort. Laura Stark (2006) recently completed a comparative study of IRBs as part of her dissertation work in the Department of Sociology at Princeton University. It is a fine study; let's hope that it is the first of many. Still, other scholars are now beginning to systematically collect information and report on problems created by IRBs (see, e.g., Mueller 2006, and http://mueller.educ.ucalgary.ca/research-ethics.html). At the panel on IRBs that followed my presidential address at the Law \& Society Association meeting, Jack Katz suggested the creation of a Web site that would allow researchers to publicly report their problematic experiences with IRBs and their resolutions. John Mueller's Web site, noted above, is, I suspect, something of a first cut at this. 
"public figure" exemption. And the IRB determines this based on a detailed application for exemption, an application just about as detailed as one submitted for full review. That is, an "exemption" here does not mean what it normally means in ordinary language: it becomes a privilege bestowed by an IRB, not a right to be exercised. ${ }^{2}$

3 . The process of applying for an exemption itself can create a moral dilemma. How candid should a researcher be, if IRB review jeopardizes even projects that should be obvious candidates for exemption? Consider researchers taking up the call advanced by Michael Burawoy (2005) in his muchcommented-upon ASA Presidential Address, or the call for a critical social science by still others such as C. Wright Mills, Pierre Bourdieu, and Nancy Scheper-Hughes, whose concerns he echoes. Researchers following their examples could easily encounter IRB approval problems. Does this sound farfetched? Consider some not-so-far-fetched possibilities.

- In his ongoing research, former LSA president and LSR editor Rick Abel explores conditions under which American lawyers, judges, and other officials embrace torture at the expense of legality. Abel is apparently keen on exposing his research subjects to risk; I take it that he would be delighted if what he wrote tarnished reputations and forced resignations. Since his work is drawn entirely from public print sources, Abel is free of IRB oversight. But suppose he began to talk to some of his research subjects, at, say, his college or law school reunions. I am fairly certain that he would be happy to obtain unflattering information about high administration officials. Should Abel report his aspirations - in response to the question about "significance" in the IRB form-in his exemption request to the UCLA IRB? Indeed, would he be in violation of IRB rules, thus barred from using what he learned in informal chats that occurred prior to his application to the IRB? I think yes.

- Consider something closer to my own research interests: cross-case vote trading between appellate court judges or between prosecutors and defense attorneys ("I'll vote your way in this case, if you vote my way in that case"). Judges

${ }^{2}$ In contrast: this past year, my 12-year-old son earned $\$ 850$. This meant that he was exempt from paying taxes. It also meant that he was exempt from having to file a tax return. He did not need to submit income information or petition for an exemption; he simply did not have to file one because he was exempt. No such luck with IRBs. 
and prosecutors are good candidates for the public figure exemption, but still, would I jeopardize IRB approval if I were candid about my interests in my application? Or would an IRB require me to disclose the purpose of my research to my subjects? If I were to ask clerks or other members of courthouse workgroups about this and had their informed consent waivers, could an IRB also insist on third-party consent-by judges and prosecutors, who are the objects of and not the subjects of the research? IRBs have been known to impose such requirements.

- Consider this dilemma, not uncommon in field research: IRB regulations require that we obtain approval before initiating research, but we often don't know we have started our research until after it is begun. To wit: last spring at a conference $I$ spoke to several current and former state commissioners of correction. These conversations led me not only to formulate a research question, but to partially answer it. Should I be able to draw on my notes from these conversations in my writing? I think so. IRBs, though, would probably say no. Prior IRB approval may feasibly be required for biomedical tests or questionnaire-based research, but it poses severe problems for other types of research whose beginnings are often discerned retrospectively, and whose nature often leads researchers to revisit field notes to investigate questions not formulated at the outset. Perhaps this type of research is not so good and should not be fostered. But is it an IRB's province to make this determination? In fact, IRBs can and do make precisely this determination, not only on an individual basis, but institutionally, as they selectively privilege certain types of inquiry within a prior restraint-like framework. Recently the faculty chair of the IRB at a well-known university informed me that if a research project is, by her lights, poorly designed, any amount of risk-even the harm associated with wasting a subject's time-is too great. Her campus's IRB had rejected, and would continue to reject, applications because of unsound methodology. I fear that this practice is not a rare exception.

- Federal regulations-at least Berkeley's version-license IRBs to inquire into not only the risks to research subjects, but the social "significance" of research. I am not sure why. Perhaps the more socially "significant" the work, the greater the range of justifiable risk ("no pain, no gain"). Such a trade-off might be reduced to a Hand-like riskbenefit formula to determine a research project is worthy of support. Again, I can understand such an approach in 
biomedical research, but it makes no sense in most social science research. Although the IRB review aims to protect research subjects, the process can attract, and has attracted, third parties who effectively intervene, formally or informally, to stifle research. Such third parties are likely to be research "objects," rather than subjects, who seek to squelch research that might portray them in an unflattering light. Cigarette companies, businesses, and university administrations come to mind here. These scenarios are not far-fetched hypotheticals - they are real problems. ${ }^{3}$

- Yet another problem is that, as with many censorship regimes, the IRB review process is highly decentralized. For example, each University of California campus has its own IRB (some have two: one for the social sciences and one for the medical school). This promises convenience-I can walk from Boalt Hall to Dwinelle Hall and hand-deliver my proposal to the IRB office staff and have face-to-face contact with them, rather than send it to an anonymous committee at a P.O. Box at the president's office in Oakland. But this convenience comes at a price. In the name of flexibility, accessibility, and efficiency, IRBs at the UCs (and in many places) are staffed by faculty who serve for limited rotating terms. There are at least three problems with this arrangement. First, continual rotation of board members leads to inconsistency and lack of institutional memory. Second, rotation and voluntary staffing leads to selfselection; self-appointed protectors of ethics gravitate to and remain on these committees (and their permanent staffs) while others quickly come and go. Third, and most troubling, IRB service seems to confirm the power of "role theory": create the position of censor, appoint a person to that position, and there is a good chance that she will act as a censor. Even our liberal, productive, researchoriented colleagues are not immune to this tendency! Furthermore, like all censorship boards, IRBs are subject to moral panics. At times they can overreact to hot-button issues of the moment, and more generally they can produce a chilling effect that turns ultimately to ice.

- Such problems, which frustrate individual researchers as they seek to get their research underway, also have important institutional and "upstream" consequences. Faced with the costly delays and changes that follow from IRBrelated challenges, researchers may abandon their projects

${ }^{3}$ In the LSA panel that immediately followed my address, participants described such efforts to squelch research. 
and settle on more easily approved forms of research. This is the case for some of my graduate students and junior colleagues at Berkeley, and I have heard of similar responses by others elsewhere. But more generally, I fear that such problems affect scholarship in several lessobvious ways. These problems may affect courses offered, they may privilege certain research methods at others' expense, and they may affect the priorities of funding agencies.

\section{IRBs as Lawless}

There may now be a generation of scholars who take this regime of censorship for granted. If so, entire research areas and methodologies are in jeopardy, insofar as the difficulties of obtaining IRB approval affect research priorities for funding agencies and universities' willingness to support researchers. This is not idle speculation: I have for years been attending panels on IRBs at meetings of professional associations, talking to colleagues who have served on IRBs, and reading the occasional article about IRBs. Furthermore, I have held the hands of two generations of graduate students who have had to navigate the minefields of IRB review. One overarching theme has consistently appeared in such encounters: reasonableness-everyone involved in administering IRBs professes to being "reasonable." Yet in exercising their reason, responsible people have rejected research proposals for lacking sufficient promised social significance; reached quite divergent conclusions, for example, when defining the scope of "public official" exceptions-even within the same university; and varied widely in their propensities to consider far-fetched hypotheticals when assessing the possibility of harm to subjects. ${ }^{4}$

What is my point in recounting all this? That IRBs can be tyrannical? Certainly. That we should be alarmed at their expanding authority? Yes. That IRBs should be reined in? Yes, all these things - but something more as well. If you are like me, you regard your campus IRB as a nuisance, to be evaded when possible, and otherwise to be approached deferentially, hat in hand, like an IRS auditor. But let me reflect more seriously on IRBs in light of the concerns with which I began this address.

We, all of us, are scholars of law and society - and, as I argued at the outset, our tradition is anchored in a jurisprudentially robust

4 In her oral presentation at the LSA panel associated with my address, Laura Stark, who has undertaken an extensive observational study of IRBs in action, described even more disturbing behavior. IRBs, she reported, regularly discuss grammatical and spelling errors - including confusion over the use of principle and principal-and use them as evidence of research competence, viewing mistakes as evidence of likely laxity in concern for the protection of their research subjects. 
conception of law. Despite this, it appears that few of us have brought our sociolegal instincts to bear on the pathologies of a censorship regime that operates in plain sight right under our noses, and that encroaches upon our research lives. Yet this is an open regime in which we can and do participate. As often as not, the enemy is in plain sight, and it is here, not "over there"; it is "us," not "them."

When held up to the standards for legality, IRBs fall short in a many respects. They substantially violate our understandings of legality and the rule of law. Lon Fuller, a leading American legal philosopher and an active supporter of this Association at its founding, wrote extensively about the conditions of legality. In his view, inherent in the concept of law is an aspiration for justice and morality. That is, the law itself makes minimal moral claims, and the extent to which a law falls short of those claims is the extent to which it fails to count as law. In a famous passage of his classic, The Morality of Law, he writes:

[In] the attempt to create and maintain a system of legal rules ... [there are] eight distinct routes to disaster. The first and most obvious lies in a failure to achieve rules at all, so that every issue must be decided on an ad hoc basis. The other routes are: 2) a failure to publicize, or at least to make available to the affected party, the rules he is expected to observe; 3) the abuse of retroactive legislation, which not only cannot itself guide action, but undercuts the integrity of rules prospective in effect, since it puts them under the threat of retrospective change; 4) a failure to make rules understandable; 5) the enactment of contradictory rules or 6) rules that require conduct beyond the powers of the affected party; 7 ) introducing such frequent changes in the rules that the subject cannot orient his action by them; and, finally, 8) a failure of congruence between the rules as announced and their actual administration (1965:39).

Fuller then observes, "A total failure of any one of these eight directions does not simply result in a bad system of law; it results in something that is not properly called a legal system at all" (1965:40). After elaborating these ideas, he draws on sociologist Georg Simmel's observation that successful governance depends on reciprocity between government and citizen. "Respect for constituted authority," Fuller reminds us, "must not be confused with fidelity to law" (1965:41). If Fuller and Simmel are correct, we may grant IRBs respect not because of their "fidelity to law," but because of their position of power. IRBs violate several of Fuller's conditions for law. Accordingly, I suggest, we cannot accord them the fidelity that law requires.

These failures are of the same sort that Judge Marvin Frankel once identified with criminal sentencing (1972). Thirty-five years 
ago, Judge Frankel wrote about vast unchecked discretion, disparities, inequalities, inconsistencies-pervasive arbitrariness in the American sentencing system. He did not simply point out that some judges abused their authority, or that the sentencing process is erratic. Rather, he argued that criminal sentencing - in conception as well as in application-was flagrantly lawless, a great "wasteland in the law." Yet Judge Frankel did not throw up his hands. Instead, he reminded his audience:

at least in one critical respect our training, our habits, and our accomplishments ought to be pertinent: we are taught and qualified to seek and formulate rules-that is law. We are steeped in a tradition of hostility to unruliness, the condition we condemn when we denounce the arbitrary and the capricious. If we have not followed [this] tradition ... it may be because we have not tried hard enough ... (1972:9).

Judge Frankel's statement about criminal sentencing in the 1970s applies today, with equal force, to the process of the ethical review of research on human subjects. ${ }^{5}$

I appreciate that my views may be more firm and fixed than those of many readers. Clearly, I have not given an utterly disinterested, nuanced, or complete account of the issues - this has not been my objective. Rather, I have sought to identify important issues that have simmered for years within our organization and within the social sciences generally. These issues may now be coming to a boil. I certainly hope so. My intention here is to turn up the heat by highlighting this growing problem as it applies to our field. I urge colleagues to discuss and debate it, through panels at LSA meetings and in other professional associations, but most of all through activities at our home institutions.

I believe there is hope. As more legal scholars begin to assess IRB activities, and as complaints about IRBs are increasingly cast in terms of rights violations, the level of concern seems to be rising (Hamburger 2004; Northwestern University Law Review 2007). Perhaps this follows the dynamic posited by Stuart Scheingold (1973) some time ago, and more recently by Michael McCann (1994) and still others in this Association: while the law itself may make little difference, litigation-or the threat thereof, or the successful invocation of the "myth of rights"-can make a difference by catalyzing social mobilization. Whatever the reasons, I am pleased to see this growing awareness of a serious problem that affects us all.

${ }^{5}$ Even in making this comparison, I hasten to qualify it. His concern was with the weak and the socially marginal. In contrast, Western academics are among the world's most privileged group. Still, this is our livelihood. And the questions raise issues of freedom of expression. For us the issue is real. 
What is to be done? I do not have a specific blueprint. But much can easily be done. As I have suggested, and as Pogo used to remind us, "We have met the enemy, and it is us." IRBs at most American universities are not foreign regimes foisted on us; they are administered by us and by our peers. Join them; subvert them - or at least curtail them. Serve on them and do all you possibly can to facilitate the research of your colleagues rather than act as a censor. Remember that federal regulations require only that federally funded research be reviewed by IRBs; urge your university to adopt and then implement a policy that spares researchers who are not federally funded from having to run the IRB gauntlet. Most of the research conducted by this Association's members is not federally funded and thus could easily be free of IRB review. At present, only a few universities - the University of Chicago comes to mind-have adopted this policy, but so far to my knowledge none of them has acted on it yet. Press for your university to opt out.

Finally, respond to opponents who would question your sensitivity to ethics in research, and demand that they document the nature and extent of the harms (see, e.g., Mueller 2006). Of course research curtailed eliminates risk of harm to an absolute zero. But press and ask about estimates of how much actual harm to subjects in social science research has been prevented by IRB actions. And ask for documentation. Of course, some harms have occurred, and others have been prevented by IRBs; one would expect all but the most ineffective bureaucracy to have some successes after 30 years and countless dollars devoted to the task. But ask whether the harms are substantial enough and frequent enough to warrant an immense bureaucratic apparatus that engages in aggressive proactive review and oversight.

Indeed, appreciate that some harms to research subjects may be desirable--isn't that what some critical and some action research is about? Many of us assign the movie Erin Brockovich or Barbara Ehrenreich's book Nickel and Dimed (2001) to our classes. Others of us are inspired by the examples of Nancy ScheperHughes, Pierre Bourdieu, and countless other committed social researchers. Why shouldn't we be able to conduct similar work ourselves?

Ask how risk-averse this process should be. Ask whether there is another, less-obtrusive alternative. Ask whether a reactive, tortlike regime for civil remedies following demonstration of harm might not be more appropriate than an elaborate proactive regulatory system. It may be debatable whether current laws on libel, slander, and copyright are sufficiently effective, but even if not, there is, so far as I know, no groundswell for a proactive regulatory regime to replace them. One reason is that principles related to free 
expression, proportionality, and the presumption of lawfulness are values engrained in American law. The American legal tradition is to set boundaries and permit freedom within them, sanctioning only those who abuse their freedom by transgressing these boundaries. IRBs, in contrast, police the interior of those boundaries in order to preempt transgression.

There is a better way to deal with abuses of human research subjects, one that is familiar to the American legal tradition, easily implemented, and able to provide redress. I hope many of us will invoke it as we critically shape the discussion in the coming crisis of IRBs.

\section{Conclusion}

I return to where I began. Brian Tamanaha warns that American law is in danger of succumbing to hyper-instrumentalism, which would turn all legal analysis into cost-benefit analysis. I hope not, because such a specter is antithetical to so much sociolegal scholarship. The most enduring work in our field-work that has appeared in the $L S R$ and been frequently cited, reprinted, and used in classrooms over the past 40 years--is work anchored in a jurisprudentially robust conception of law. Certainly, however, this tradition needs to be nurtured and strengthened. If we give way to hyper-instrumentalism, I have suggested, then we will suffer in at least three respects. First, as this Association continues to engage in the globalization project, we (and particularly American members) are in danger of failing to appreciate vast areas of legal life and bodies of sociolegal scholarship that are anchored in a different, less-instrumental, and more jurisprudentially rich view of law. Second, engagement in public scholarship requires a normative anchor, and a jurisprudentially rich concept of law can provide such an anchor.

Finally, as we reflect on our own lives as scholars, we need a firm foundation upon which to assert ourselves against those who, in the name of doing good, would curtail our work. I have discussed this last concern at some length because of the pressing nature of the problem, and because I believe that collectively we have failed to bring the tools of our trade to address the problem. We have not invoked the principles of law and legality in diagnosing the problems in efforts to protect the integrity of our research. We have remained all too silent as a stifling regime of regulations has been erected around us. In an era of strident deregulation, this is all the more surprising. It is time, well past time, for us to begin to assert our concerns, to express them in legally salient 
terms - rights, censorship, prior restraint, and the like-in order to make them more widely understood and more forceful.

The Law \& Society Association provides an ideal forum for expanding and intensifying this emerging discussion about IRBs. ${ }^{6}$ Our tradition values the principle of legality and embraces the idea of public and critical scholarship. As such our membership, both institutionally and individually, has an obligation to play an active part in this growing debate.

\section{References}

Auerbach, Carl A. (1966) "Legal Tasks for the Sociologist," 1 Law E Society Rev. 91-104. Black, Donald (1980) The Behavior of Law. New York: Academic Press.

Burawoy, Michael (2005) "2004 Presidential Address: For Public Sociology," 70 American Sociological Rev. 4-28.

Constable, Marianne (2005) Just Silences: The Limits and Possibilities of Modern Law. Princeton, NJ: Princeton Univ. Press.

Driesen, David (2002) "Does Natural Law Thinking Drive Law and Economics?" Paper presented at the annual meeting of the Law \& Society Association, Vancouver, British Columbia.

Edelman, Lauren B., et al. (1993) "Internal Dispute Resolution: The Transformation of Civil Rights in the Workplace," 27 Law E Society Rev. 497-534.

Ehrenreich, Barbara (2001) Nickel and Dimed: On (Not) Getting By in America. New York: Henry Holt.

Erlanger, Howard S. (2005) "Presidential Address: Organizations, Institutions, and the Story of Shmuel: Reflections on the 40th Anniversary of the Law \& Society Association," 39 Law \& Society Rev. 1-10.

Feeley, Malcolm (2005) "Three Voices of Socio-Legal Studies," 35 Israel Law Rev. $175-82$.

Frankel, Marvin E. (1972) "Lawlessness in Sentencing," 41 Univ. of Cincinnati Law Rev. $1-79$.

Fuller, Lon L. (1965) The Morality of Law, rev. ed. New Haven, CT: Yale Univ. Press.

Hamburger, Philip (2004) "The New Censorship: Institutional Review Boards," 2004 Sup. Ct. Rev. 271-354.

Harrington, Christine (2007) "The Impact of Institutional Review Boards (IRBs) on Law \& Society Researchers." Report, Membership and Professional Issues Committee, Law \& Society Association, 6 July.

Katz, Jack (2006) "Ethical Escape Routes for Underground Ethnographers," 33 American Ethnologist 499-506.

McCann, Michael W. (1994) Rights at Work: Pay Equity Reform and the Politics of Legal Mobilization. Chicago: Univ. of Chicago Press.

Mueller, John (2006) "Ignorance Is not Bliss, Nor Ethical." Unpublished paper distributed at the annual meeting of the Law \& Society Association, Baltimore, Maryland, July $5-8,2006$.

Northwestern University Law Review (2007) "Symposium: Censorship and Institutional Review Boards," 101 Northwestern University Law Rev.

${ }^{6}$ The Association has already taken some steps in this direction. Its Membership and Professional Issues committee was charged to investigate and report on problems members faced in dealing with IRBs, and to this end it submitted a process report to the Board of Trustees at the 2007 annual meeting in Berlin (Harrington 2007). 
Sarat, Austin (2005) The Death Penalty: Influences and Outcomes. Aldershot, United Kingdom: Ashgate Publishing.

Scheingold, Stuart A. (1973) The Politics of Rights: Lawyers, Public Policy, and Political Change, 2d ed. Ann Arbor, MI: Univ. of Michigan Press.

Scheingold, Stuart, \& Sarat Austin (2004) Something to Believe In: Politics, Professionalism, and Cause Lawyering. Stanford, CA: Stanford Univ. Press.

- (2005) Cause Lawyering and the State in a Global Era. New York: Oxford Univ. Press.

Selznick, Philip (1969) Law, Society, and Industrial Justice. New York: Russell Sage.

Skolnick, Jerome (1966) "Social Research on Legality: A Reply to Auerbach," 1 Law $\Xi$ Society Rev. 105-10.

Stark, Laura (2006) "Morality in Science: How Research Is Evaluated in the Age of Human Subjects Research." Ph.D. dissertation, Department of Sociology, Princeton University.

Tamanaha, Brian (2006) Law as a Means to an End: Threat to the Rule of Law. New York: Cambridge Univ. Press.

Teubner, Gunther (1983) "Substantive and Reflexive Elements in Modern Law," 17 Law E Society Rev. 239-86. (1984) "Autopoiesis in Law and Society: A Rejoinder to Blankenburg," 18 Law E Society Rev. 291-301.

Trubek, David (1988) “The Handmaiden's Revenge: On Reading and Using the Newer Sociology of Civil Procedure," 51 Law and Contemporary Problems 111-34.

Malcolm M. Feeley is Professor of law at the University of California at Berkeley. He has taught at NYU, Yale, Wisconsin, and, since 1984, Berkeley. He is the author of a number of books and articles, including the forthcoming books: (with Edward Rubin) Federalism: Political Identity and Tragic Choice (Univ. of Michigan Press), and (with Terence Halliday and Lucien Karpik, eds.) The Legal Complex and Struggles for Political Liberalism (Hart). A student editor of the LSR on Vol. 2, No. 2, and a longtime member of the Law E Society Association, he has served as its president from 2005 to 2007. 